\title{
Tabularia
}

TABULARIA Sources écrites des mondes normands médiévaux Autour des sagas : manuscrits, transmission et écriture de l'histoire | 2015

\section{Árni Magnússon, an early-modern collector of medieval manuscripts}

Árni Magnússon, un collectionneur de manuscrits médiévaux du début de l'époque moderne

Árni Magnússon, un collezionista di manoscritti medievali all'inizio dell'età moderna

Már Jónsson

\section{OpenEdition}

\section{Journals}

Electronic version

URL: http://journals.openedition.org/tabularia/2218

DOI: 10.4000/tabularia.2218

ISSN: $1630-7364$

Publisher:

CRAHAM - Centre Michel de Boüard, Presses universitaires de Caen

Electronic reference

Már Jónsson, «Árni Magnússon, an early-modern collector of medieval manuscripts », Tabularia

[Online], Autour des sagas : manuscrits, transmission et écriture de l'histoire, Online since 14

December 2015, connection on 19 April 2019. URL : http://journals.openedition.org/tabularia/2218 ; DOI : 10.4000/tabularia.2218 


\title{
Árni Magnússon, an early-modern collector of medieval manuscripts
}

\section{Árni Magnússon, un collectionneur de manuscrits médiévaux du début de l'époque moderne \\ Árni Magnússon, un collezionista di manoscritti
medievali all'inizio dell'età moderna}

\author{
Már JónsSON \\ University of Iceland \\ marj@hi.is
}

\begin{abstract}
:
The article provides an overview of the life and work of the Icelandic scholar Árni Magnússon (1663-1730), collector of manuscripts and professor of history at the University of Copenhagen. He started collecting Icelandic manuscripts as a young man and his collection is now the basis for all research on Medieval Iceland. It also contains Norwegian and Danish medieval manuscripts, as well as more recent Icelandic ones.
\end{abstract}

Keywords: Medieval manuscripts, history of scholarship, early modern intellectual history, Icelandic history, Árni Magnússon/Arnas Magnæus

Résumé:

L'article donne un aperçu de la vie et de l'œuvre du savant islandais Árni Magnússon (16631730), collectionneur de manuscrits et professeur d'histoire à l'Université de Copenhague. Alors qu'il était encore un jeune homme, il a commencé à recueillir des manuscrits islandais. Sa collection est maintenant la base de toute recherche sur l'Islande médiévale. Elle comprend également des manuscrits médiévaux norvégiens et danois, ainsi que des manuscrits islandais plus récents.

Mots-clés: manuscrits médiévaux, histoire de l'érudition, histoire intellectuelle du début de l'époque moderne, histoire islandaise, Árni Magnússon/Arnas Magnous

Riassunto:

Questo articolo offre uno squarcio sulla vita e l'opera dell'intellettuale islandese Árni Magnússon (1663-1730), collezionista di manoscritti e professore di storia all'Università di Copenhagen. Quando ancòra era giovane, cominciò a raccogliere manoscritti islandesi. La sua collezione è attualmente alla base di tutte le ricerche sull'Islanda medievale. La collezione comprende anche manoscritti norvegesi e danesi, nonché codici islandesi più recenti.

Parole chiave: manoscritti medievali, storia dell'erudizione, storia intellettuale dell'epoca moderna, storia islandese, Árni Magnússon/Arnas Magnous 
In the seventeenth and eighteenth centuries scholars all over Europe chased manuscripts, even in remote Iceland, where interest in the old literature and historical works increased greatly in the first decades of the seventeenth century. The Icelandic historian Árni Magnússon, or Arnas Magnæus as he was known in Latin (Jules Verne's "Arne Saknussem"), although not among the earliest manuscript hunters in Iceland, was far and away the most determined and successful of them. His craving for vellum manuscripts was a part of the early Enlightenment's wish to define historical research as a rational and systematic discipline, unburdened by political interest and religious bias.

Árni Magnússon, now regarded as one of Iceland's national heroes, was born on 13 November 1663 . His father was a priest, as were both his grandfathers and his two brothers. He went to Copenhagen when he was nineteen years old to study at the University and a year later became amanuensis to the newly appointed Royal Antiquarian, Thomas Bartholin the younger. Árni worked for him for six years, then spent two years in Germany and on his return to Copenhagen in 1697 he became secretary to the Royal Danish Archives. Four years later, at the age of 38 , he was appointed professor of history at the University of Copenhagen, a position later held by the Norwegian playwright and historian Ludvig Holberg. Árni then spent ten years in Iceland as a member of a royal commission whose brief it was to make a register of all farms in the country, take a census, both of people and livestock, and, not least, check to see whether law and order were being properly maintained. It was a thorough investigation of conditions in Iceland that aimed at the economic and political recovery of this extremely poor country of only 50 thousand inhabitants. After his return to Copenhagen in 1713, Árni spent a quiet life as professor, archivist and librarian until his death on 7 January $1730^{1}$.

Árni Magnússon's energy throughout his life was chiefly devoted to assembling the collection of manuscripts which now bears his name, divided between two Arnamagnæan Institutes at the universities of Reykjavík, Iceland, and Copenhagen, Denmark ${ }^{2}$. Árni's collection contains some 2500 items, the oldest dating from the early twelfth century. Vellum manuscripts comprise about one fifth of the collection; many of these are fragmentary or defective, since Árni appreciated that even the smallest pieces could have cultural and historical significance. The bulk of the collection, however, consists of post-medieval manuscripts which he got hold of or paid scribes to write for him. Manuscripts containing texts of the renowned Icelandic family sagas number about two hundred in his collection. Árni also collected documents and charters, and possessed, at the time of his death, roughly five thousand original diplomas and ten thousand transcripts. More than half of these are from Iceland.

1. This, and most of what follows, is based on my two books on Árni Magnússon, Jónsson, 1998 and JónsSON, 2012. A concise overview of Árni's life is available in BEKKER-NIELSEN and WIDDING, 1972.

2. On the issue of the return of the manuscripts to Iceland, see DAvíĐSDótTiR, 1999. 
Collecting manuscripts can be seen as an intellectual activity in the sense that their content is, or at least can be, more important than their looks. Many manuscripts are of course important as artefacts and are thus collectable because of their beauty, but the purpose then is more to admire them than to read them. When scholars in Alexandria in the first and second centuries of the Common Era searched for manuscripts of the works of Homer they hoped to arrive at a complete text. Good manuscripts were old manuscripts, and one manuscript could supplement another. This attitude towards quality and old age culminated in Italy in the fourteenth and fifteenth centuries. The poet Petrarch was a pioneer in such matters, as in so many other things, but more important were the travels of the scholar Poggio Bracciolini in France, Germany and England, where he searched for manuscripts in convents and churches. Works from Greek and Roman antiquity came to light which were previously unknown, as well as new and better manuscripts of works that were already known and appreciated ${ }^{3}$.

The greatest collection of manuscripts was put together by Lorenzo di Medici in Florence, who died in 1494. He sent men to search for manuscripts in Greece, Constantinople and southern Italy. He did not study the manuscripts himself but his collection was open to scholars. Angelo Poliziano was the most important scholar among the Italian humanists and he realised that the majority of manuscripts could not be trusted. Poliziano therefore claimed that it was necessary to get as close to the original manuscript as possible, using young manuscripts only when it could be ascertained that they were good copies of old manuscripts ${ }^{4}$.

In the seventeenth century scholars desperately searched for manuscripts, and their field of interest was no longer limited to Greek and Roman antiquity but also medieval Europe. In Iceland too, interest in the medieval national literature increased greatly, and learned men in Denmark and Sweden began studying medieval Icelandic texts with the aid of Icelandic students and travellers. This led to a frantic search for medieval manuscripts. Most of them belonged as family treasures to rich families, or as the Rev. Magnús Ólafsson wrote to the Danish scholar Ole Worm in 1632: lay people in Iceland who had manuscripts "sat on them like dragons on gold" 5 . But when both bishops showed interest and wanted to have manuscripts, the owners decided to part with them. The first really ambitious and successful collector of Icelandic manuscripts was Brynjólfur Sveinsson, who became bishop of Skálholt in 1639. He had a special gift for discovering important manuscripts and the persuasive powers to make their owners part with them. In 1656, bishop Brynjólfur sent some extremely important manuscripts to King Frederik III of Denmark, hoping that he would

3. Reynolds and Wilson, 1991, p. 31, 104-105 and p. 130-139; RiCO, 1986, p. 47-48; SHePHerD, 1802, p. 54 and p. 99-100.

4. Rizzo, 1973, p. 176-179; Grafton, 1977, p. 150-188; Reynolds and Wilson, 1991, p. 143-144.

5. Ole Worm's Correspondence..., 1948, p. 225: “Laici autem nostri, qvi tales antiqvorum relationes possident, agre communicant, sed iis aut angvis auro incubant, nullo cum fructo, nisi ut tempus aliqvando fallant". A Danish translation can be found in Breve fra og til..., 1965, vol. I, p. 273. 
have the texts published and translated into Latin. Among these manuscripts was the famous Flateyjarbók, containing sagas of Norwegian kings, written in 13871394. In 1662, the king sent the Icelandic scholar Pormóður Torfason (Tormod Torfæus) to Iceland in order to collect manuscripts and bishop Brynjólfur, again, handed him the famous codex of the Poetic Edda, another of the Prose Edda and an incomplete vellum of Njáls saga.

Simultaneously with the rediscovery of medieval manuscripts there was a rush to transcribe them so that more than one person could study the texts or just read them for pleasure. This led to a greater dissemination of medieval Icelandic texts within the country and the revival of the saga heritage, although strictly limited to the educated upper class and some wealthy farmers. The first editions of Icelandic texts, some of them with Latin translations for the international book market, were published in Sweden and Denmark in the 1660 s and in Iceland in 1688.

After graduating from the Cathedral school in Skálholt in the spring of 1683 , Árni Magnússon went to Copenhagen, where he took a theological degree in 1685. He would probably have become a priest in Iceland had he not met the Royal Antiquarian Thomas Bartholin, who hired him as his assistant in the summer of 1684 , as mentioned previously. The following months were spent perusing manuscripts of uneven quality, and Árni took hundreds of excerpts from Icelandic family sagas and sagas of Norwegian and Danish kings. Early on, therefore, Árni had a detailed and wide-ranging knowledge of medieval Icelandic literature. His method of transcribing was traditional, which is to say not very exact. He wrote using his own orthography and copied from whatever manuscripts were available, most of them quite recent and of varying quality. That did not really matter, though, since the primary purpose was to get information on medieval culture and history and not to establish a good or correct text.

Thomas Bartholin understood some Icelandic, it seems, but did not know much about Icelandic medieval literature. He had a faint idea, however, that there were manuscripts in Iceland that could be obtained and should be brought to Copenhagen, just as Danish runestones had been brought there earlier. His predecessor as Royal Antiquarian, the Icelander Hannes Porleifsson, had perished with a ship on his way from Iceland in 1682 and we do not know how many manuscripts vanished with him. That same year the wealthy but somewhat unruly Jón Eggertsson brought numerous and valuable Icelandic manuscripts to Sweden. The rivalry between Swedes and Danes was great in these years, resulting in intermittent warfare, and both sides claimed more ancient and glorious origins than the other and used Icelandic texts to support their claims ${ }^{6}$. Bartholin promptly suggested there should be a Danish monopoly on the collecting of manuscripts in Iceland, and wrote to the king on 4 April 1685, that "since it is known that our neighbours have obtained from Iceland a great many beautiful manuscripts which they issue in print thereby causing us the greatest detriment,

6. Skovgaard-Petersen, 1993 and Skovgaard-Petersen, 2002. 
I beseech most humbly your Royal Majesty that you command your treasurer in Iceland, Christofer Heidemann, that he shall not only forbid and see to it that no written histories or documents be sold out of the country to foreigners, but also that he collect all manuscripts that he can get hold of and send them to Copenhagen"7.

Bartholin also pointed out that one of his tasks was to publish Icelandic sagas and had for that purpose hired Icelandic students. One of them would be sent to Iceland in order to collect manuscripts and documents. This was Árni Magnússon, and since the king accepted everything Bartholin said, the two of them, Árni and Heidemann, went to Iceland in the spring of 1685 with the explicit aim of collecting manuscripts. Árni returned to Copenhagen a year later but hardly brought anything of interest for Bartholin, who was clearly disappointed. But what else was to be expected? Árni was not wealthy enough to travel around the country and he was too young to have the connections necessary for the kind of success he had later in life. However, for his own library he got hold of three venerable fourteenth-century manuscripts of the lawbook Jónsbók of 1281 from family and friends. This was his first serious contact with vellum manuscripts, and judging from the incredible progress in his working-methods during the next few years, one suspects that he had some sort of a secular revelation and was filled with respect and at the same time an ardent desire to get more, either by buying "real" manuscripts or by making copies.

In 1689 Bartholin published his book on the heroic Danes of ancient times, Antiquitatum danicarum de causis contemptae a danis adhuc gentilibus mortis, praising Árni in the introduction. Unfortunately, Bartholin died in November 1690, only 33 years old, and Árni was asked to continue the work on a multi-volume ecclesiastical history of Denmark on which Bartholin had been working. He accepted the offer but never actually did anything, being more interested, as it seems, in the history and literature of his own country. In 1696 he bragged that he now possessed copies of all important Icelandic works, and three years later he stated that he had the best collection of Icelandic manuscripts in the world. And indeed, from then on most of his time was spent collecting and transcribing medieval manuscripts and documents.

Árni did not have the means to travel to Europe for further study, as many of his Danish and Norwegian friends did. But by a stroke of luck he got to spend two and a half years in Germany. In May 1694 the assembly of professors at the University of Copenhagen decided to send Arnas Magnoeus Islandus off to the town of Stettin in Pommern (now in Poland) in order to receive a collection of Oriental manuscripts and books that the renowned scholar Andreas Müller Greiffenhagen wished to give to the University Library on the promise that it would be kept intact and in good order. Müller was famous for his claim to have devised a key to the Chinese language and its writing, but never published anything nor proved willing to provide details to other scholars. The trip must

7. Hermannsson, 1929, p. 57-58 
have come as a relief for Árni, who hardly had money enough to sustain himself in Copenhagen. The negotiations with Müller came to nothing, however, and he died later that same year, allegedly having burnt all his papers, and the great philosopher Leibniz deplored the loss of his key to the Chinese language: "If only he had explained the whole affair frankly to those who could have understood it, he would without doubt have received the desired aid of great princes and especially of his lord"s.

Árni, luckily, was allowed to continue his journey, since his patrons, as he called them, wanted him to do some research on Danish church history in German libraries. Árni arrived in Leipzig in late August 1694. The city was an important centre of publishing and its book fair had become the largest of its kind. The University Library, the Bibliotheca Paulina, was renowned for its collection of books and manuscripts. Going to such a city and living there for some time most certainly was a great experience for a young and ambitious scholar, not least if the situation in Copenhagen was as bad as Robert Molesworth claimed in London that same year: "Denmark has formerly produced very Learned Men, such as the famous Mathematician Tycho Brahe, the Bartholines for Physick and Anatomy, Borichius, who died lately... But at present Learning is there at a very low Ebb... There is but one University, which is at Copenhagen, and that mean enough in all respects; neither the Building nor Revenues being comparable to those of the worst of our single Colleges"'.

The rather conservative University of Leipzig had for a while been popular with Danes and Norwegians, and in the autumn of 1693 a close friend of Arni's went there to study. A Norwegian friend of his was on his way when Árni arrived, as were two other Norwegians. This was the company he wanted to keep, and books were a common obsession. Árni enrolled for the autumn semester of 1694 but probably never attended the university on a regular basis. Enrolment may have been a prerequisite for gaining access to the University Library, which was on the upper floor of a former Dominican monastery built at the end of the fifteenth century, with an arched roof and religious paintings on the walls. This is where Árni spent most of his time during the next two years. According to the Swedish scholar Olof Celsius, who met Árni in the spring of 1696, they went early in the morning to the librarian Christoph Pfautz, also professor of mathematics, in order to fetch the keys and after that roamed freely among the books and manuscripts, without supervision ${ }^{10}$.

Árni never knew when his mentors would order his return to Copenhagen, and to judge from the mass of extant notes on manuscripts and books he must have worked at a furious pace. During his stay, Árni had only two things on his mind, manuscripts and printed books. Previously he had only had access to Icelandic, Norwegian and Danish manuscripts, and the libraries in

8. LeIBNIZ, 1994, p. 56

9. Molesworth, 1694 , p. 233-234.

10. Árni Magnússons levned..., 1930, vol. I, 2, p. 157. Most of what follows on Árni's stay in Leipzig is based on my article, Jónsson, 1999; see also Jónsson, 2010. 
Copenhagen were not particularly good. But this was another world, and he thoroughly enjoyed it. For manuscripts in the University Library he used a catalogue published in 1686, already known to him from the private library of Thomas Bartholin. Once in Leipzig, Árni used it as a reference point, perusing manuscripts that he found interesting. Of almost 1000 manuscripts listed in the catalogue, Árni took a close look at around 50. He was mainly interested in chronicles and other medieval historical works on the one hand and lives of saints on the other. The former category relates to his work on Danish ecclesiastical history. It was therefore natural that Pommern was one of the most interesting areas, due to its proximity to Denmark. Leipzig, however, was hardly the right place for this kind of research, and Árni should have kept to archives and libraries closer to Denmark. He probably did not care too much about that, though, since his historical (and authentic) interests were wider than this. He even delighted in reading chronicles on events from before the birth of Christ and made a note that one of the manuscripts was beautifully written: "eleganterque exaratus". Another manuscript inspired him to draw a genealogy of the emperor Charlemagne.

One thing Árni delighted in was comparing manuscripts he found in Leipzig with printed editions of the same works. To take an example, he compared an edition of the thirteenth century chronicle of Martinus Polonus with four manuscripts in the University Library, writing excerpts from the edition as the main text and variants from the manuscripts in a spacious margin to the right. He was highly critical of editions where the orthography had been changed and the text thus corrupted. As for the lives of saints his interest may have had something to do with his search for information on Danish ecclesiastical history, but it also connects closely to Árni's previous work on Icelandic bishops in the Middle Ages, besides his admiration for scholarly editions at the time being produced in Antwerp and Paris.

It is possible that one of Árni's duties for the men who sponsored him was to buy books for their private collections or possibly even for the University Library in Copenhagen. This is never made clear in his letters, but judging from the endless lists of books which he assembled during his months in Leipzig it seems not unlikely. Árni himself was seriously infected with the desire to own books and he bought hundreds of them, mostly recent books available in bookshops. He had a special fondness for the works of Hermann Conring, an influential professor of politics at the University of Helmstedt until his death in 1681, and made two lists with titles of books that Conring had written. One two-page list contains 40 books from the years 1641-1695, most of them on political thought. On top of both pages Árni has written "hoec habeo" and "habeo hoec Omnia" - I have them all! On top of the other list, with the titles of over 60 books by Conring, he wrote that those that were underlined he owned: "de understrogede hâr ieg".

But not everything could be bought, and Árni did not have that much money. In the Leipzig University Library he read or at least leafed through thousands of books, making lists of titles and taking a few notes - only on rare occasions adding comments of his own. He was not a polyhistor in the sense 
that all subjects fascinated him ${ }^{11}$. He concentrated on history and geography, but ranged far and wide within that field. He looked at travel books, atlases and general works on geography, showing a particular interest in Hungary. He noted different ways of calculating the years from the creation of the world, at one point working out that 5199 minus 2957 was 2242, but this was all done within the context of textual studies, never from a theological point of view. He made a list of books on the subject of the invention of writing and was interested in books on the female pope Joan, claiming in the margin of a note on the Historical discourse on popess Joan, published by Johann Conrad Dieterich in 1655, that it was interesting but badly written.

His greatest passion was for books from the period 1480 to 1520 , which were available in great abundance in the Bibliotheca Paulina. Historical works by the Italian humanists attracted his attention, especially Flavio Biondo, of whose books he made a detailed study. What fascinated Árni about really old books was the fact that many of them were the first printed editions of old and important historical works concerned with the medieval history of Europe. He notes, for instance, that in the preface to The History of the Goths by Jordanes and The History of the Longobards by Paulus Diaconus, published in 1515, the editor Konrad Peutinger claims that this was the first edition ever. And just as he compared editions with manuscripts available in Leipzig, Árni compared first editions with more recent editions. To take an example, Conring's edition of Germania by Tacitus of 1678 compared favourably with the first edition of 1470 . Árni collated the entire text line for line, explaining in the end that he had left out gross and obvious typographical errors: "crassiora et manifesta typographica vitia omisi". Could anyone be trusted?

Árni was, to take another example, not at all satisfied with editions of old historical works from the library of Johann Pistorius. Pistorius died in 1608 and a posthumous collection of his works was published a few years later. Árni had before him the huge volumes of the Veterum Scriptorum rerum Germanicarum... ex bibliotheca Pistorii, printed in Frankfurt in 1613, and the Rerum Germanicarum Veteres, printed forty years later. Whether he read the entire work is impossible to say, but having seen an edition of German chronicles published in Mainz by Johannes Schöffer in 1521, he compared it to Pistorius and was not impressed by the latter, since the other edition was so much better: "Hoec editio longe melior est Pistorianâ".

Árni left Leipzig in September 1696 and would have liked to travel through Holland and England but had no money, and his protectors were apparently not as interested in prolonging his journey as he was. He already knew, to no avail, that libraries in Utrecht, Leiden and Amsterdam stayed open two days a week, but were accessible all days in London and Oxford. From Leipzig he travelled through Halle and remembered later that Johann Gottfried Olearius had not been at home so he could not see his renowned museum. In Helmstedt he saw

11. On that concept, see Grafton, 1985 
a painting of an extremely tall man who had been in the service of the count of Lüneburg, noting that his crutch was almost as long as Árni himself. He met the librarian Melchior Schmid and got to see manuscripts from the collection of the great polyhistor Caspar Sagittarius, who died in 1694. In Wittenberg he saw a commentary written by the Byzantine scholar Isaac Tzetze in the twelfth century on the poems of Lycophron.

Back in Copenhagen Árni started working in the Royal Archives. He hardly ever used any of the knowledge he had acquired in Leipzig, although at times later in life he made fond but short notes on his journey. His love for manuscripts and books never diminished, however. When in Iceland in the years 1702-1712, as he investigated political issues for the king, he corresponded with and talked to hundreds of people, always asking the same questions: did they have any manuscripts, had they seen any dispersed vellum leaves or perhaps had some in the bindings of their books? Most vellum manuscripts had already been taken out of the country, but Árni knew that there were many old manuscripts left in a fragmentary state. He was able to reconstruct several of these, gradually gathering the pieces together from different people and different parts of the country, showing remarkable patience and perseverance, the likes of which had not been previously seen. He virtually scoured the country so that there was not much left when he returned to Copenhagen in 1712. No piece of vellum or old paper was neglected. We are fortunate that normally Árni wrote a note on where he got the manuscript and who had owned it before, and also, often, some thoughts on the contents and value of the text or the manuscript itself. If he could not buy manuscripts and documents or get them as a gift, he hired good scribes to copy them with the greatest accuracy and vigilance, for instance thousands of original documents that were too important to their owners to part with. Or, in his own succinct and highly sympathetic words in a letter to the king in 1721: "On my journeys to Iceland there came to me, time and again, many old books, including a number of illegible letters and other such things, which I, where the owners did not object thereto, have acquired for payment. The remainder, which the owners either would not or could not give up, I have copied, solely to the end that such materials should be saved from destruction, since most in that country care now not greatly for such things" ${ }^{12}$.

After Árni settled in Copenhagen again he bought manuscripts at auctions, and when Pormóður Torfason (Torfæus) died in 1719 he acquired his collection of manuscripts. Once in a while he got packets from Iceland, for instance one with thirty-three vellum leaves from his nephew Snorri Jónsson in 1721. The collection continued to grow, and Árni nurtured hopes that he would manage to make a catalogue before he died, which did not happen. Nor did he publish any editions of Icelandic texts or write learned books on them - obsessed as he was with his collection. His life's work of collecting manuscripts might also have come to nothing. On the evening of 20 October 1728 a fire broke out in

12. BeKKer-Nielsen and Widding, 1972, p. 32. The last part of the article, again, is based on my two books on Árni Magnússon. 
Copenhagen. It raged for three days, destroying at least one-third of the city. Árni waited too long and did not order the removal of his belongings from his house in Kannikestræde until it was almost too late. Only a few dozen manuscripts perished, but almost all his printed books, those bought in Leipzig and later, and many of his erudite notes and papers were lost in the fire, burning to ashes in just half an hour. The same fire destroyed the University Library, of which he was the custodian, with numerous valuable Icelandic, Norwegian and Danish vellum manuscripts. The destruction was a terrible blow to Árni, and he died fourteen months later, on 7 January 1730, having bequeathed his collection to the University of Copenhagen the day before. In his will he made provision for a stipend, sufficient for one or two scholarships in the field of Icelandic history and literature. There are now scholars by the dozens working in the two institutes that bear his name, watching over the manuscripts and keeping Icelandic medieval heritage alive, just as he would have wanted.

\section{Bibliography}

Árni Magnússons levned og skrifter, ed. Finnur Jónsson, Copenhagen, Gyldendal, 1930, 2 vols.

Berker-Nielsen, Hans and Widding, Ole, Arne Magnusson, the manuscript collector, trans. Robert W. Mattila, Odense, Odense University Press, 1972.

Breve fra og til Ole Worm, ed. and trans. H.D. SCHEPELERn, Copenhagen, Munksgaard, 1965, 3 vols.

DAvíĐSDótTIR, Sigrún, Håndskriftsagens saga i politisk belysning, trans. Kim LembeK, Odense, University Press of Southern Denmark, 1999.

Grafton, Anthony, "On the scholarship of Politian and its context", Journal of the Warburg and Courtauld Institutes, 4O, 1977, p. 150-188.

Grafton, Anthony, "The World of the Polyhistors: Humanism and Encyclopedism", Central European History, 18, 1985, p. 31-47.

Hermannsson, Halldór, Icelandic Manuscripts, Islandica XIX, Ithaca, Cornell University Press, 1929.

Jónsson, Már, Árni Magnússon: Ævisaga, Reykjavík, Mál og menning, 1998.

Jónsson, Már, "Arnas Magnæus Islandus: A visiting scholar in Leipzig, 1694-1696", Lias, 26, 1999, p. 213-232.

Jónsson, Már, "Manuscript Hunting and the Challenge of Textual Variance in Late Seventeenth-Century Icelandic Studies", in The Making of the Humanities I, ed. Rens BoD, Jaap MAAT and Thijs Weststeijn, Amsterdam, Amsterdam University Press, 2010, p. 309-321.

Jónsson, Már, Arnas Magnaeus Philologus (1663-1739), Odense, University Press of Southern Denmark, 2012.

Leibniz, Gottfried Wilhelm, Writings on China, ed. and trans. Daniel J. Cook and Henry Rosemont, Chicago and La Salle, Open Court, 1994.

Molesworth, Robert, An Account of Denmark as it was in the Year 1692, Third Edition, London, 1694. 
Ole Worm's Correspondence with Icelanders, ed. Jakob BenediKtsson, Copenhagen, Ejnar Munksgaard, 1948.

Reynolds, Leighton Durham and Wilson, Nigel Guy, Scribes and Scholars: A Guide to the Transmission of Greek and Latin Literature, Third edition, Oxford, Clarendon Press, 1991.

Rico, Francisco, "Philology and Philosophy in Petrarch", in Intellectuals and Writers in Fourteenth-Century Europe, ed. Piero Boitani and Anna Torti, Tübingen and Cambridge, G. Narr, 1986, p. 45-66.

Rizzo, Silvia, Il lessico filologico degli umanisti, Rome, Edizione di storia e letterature, 1973.

Shepherd, William, The Life of Poggio Bracciolini, Liverpool, J. M'Creery, 1802.

Skovgaard-Petersen, Karen, “The Literary Feud between Denmark and Sweden in the Sixteenth and Seventeenth Century and the Development of Danish Historical Scholarship", in Renaissance Culture in Context: Theory and Practice, ed. Jean R. Brink and William F. Gentrup, Aldershot, Scolar Press, 1993, p. 114-120.

SKovgaARD-Petersen, Karen, Historiography at the court of Christian IV (1588-1648): Studies in the Latin histories of Denmark by Johannes Pontanus and Johannes Meursius, Copenhagen, Museum Tusculanum Press, 2002. 